\title{
Comparison of Plateletpheresis on the Fenwal Amicus and Fresenius Com.Tec Cell Separators
}

\author{
Fevzi Altuntas $^{\mathrm{a}} \quad$ Ismail Sari $^{\mathrm{b}} \quad$ Ismail Kocyigit ${ }^{\mathrm{a}} \quad$ Leylagul Kaynar $^{\mathrm{a}} \quad$ Sibel Hacioglu $^{\mathrm{b}}$ \\ Ahmet Ozturk $^{c} \quad$ Mehmet Oztekin $^{\mathrm{a}} \quad$ Musa Solmaz $^{\mathrm{a}}$ Bulent Eser $^{\mathrm{a}}$ Mustafa Cetin $^{\mathrm{a}}$ Ali Unal $^{\mathrm{a}}$ \\ a Department of Hematology and Apheresis Unit, Erciyes Medical School, Kayseri \\ ${ }^{b}$ Department of Hematology, Pamukkale Medical School, Denizli \\ ${ }^{\mathrm{c}}$ Department of Statistics, Erciyes Medical School, Kayseri, Turkey
}

\section{Key Words}

Plateletpheresis · Apheresis · Amicus · COM.TEC .

Cell separator

\section{Summary}

Background: A variety of apheresis devices are now available on the market for plateletapheresis. We compared two apheresis instruments (Fenwal Amicus and Fresenius COM.TEC) with regard to processing time, platelet (PLT) yield and efficiency, and white blood cell (WBC) content. Material and Methods: Donors undergoing plateletpheresis were randomly separated into two groups (either the Amicus or the COM.TEC cell separator). Results: In the pre-apheresis setting, 32 plateletpheresis procedures performed with each instrument revealed no significant differences in donors' sex, age, weight, height and total blood volume between the two groups. However, the preapheresis PLT count was higher with the COM.TEC than with the Amicus $\left(198 \times 10^{3} / \mu \mathrm{l}\right.$ vs. $\left.223 \times 10^{3} / \mu \mathrm{l} ; p=0.035\right)$. The blood volume processed to reach a target PLT yield of $\geq 3.3 \times 10^{11}$ was higher in the COM.TEC compared to the Amicus $(3,481$ vs. $2,850 \mathrm{ml} ; \mathrm{p}<0.001)$. The median separation time was also significantly longer in the COM.TEC than in the Amicus (61 vs. 44 min; $p<0.001)$. 91 and $88 \%$ of the PLT products collected with the Amicus and the COM.TEC, respectively, had a PLT count of $\geq 3.3 \times 10^{11}(p=0.325)$. All products obtained with both instruments had WBC counts lower than $5 \leftrightarrow 10^{6}$, as required. There was no statistical difference with regard to collection efficiency between the devices $(55 \pm 15$ vs. $57 \pm 15 \% ; p=0.477$ ). However, the collection rate was significantly higher with the Amicus compared to the COM.TEC instrument $(0.077 \pm 0.012 \times$ $10^{11}$ vs. $\left.0.057 \pm 0.008 \times 10^{11} \mathrm{PLT} / \mathrm{min} ; \mathrm{p}<0.001\right)$. Conclusion: Both instruments collected platelets efficiently. Additionally, consistent leukoreduction was obtained with both instruments; however, compared with the COM.TEC instrument, the Amicus reached the PLT target yield more quickly.

\author{
Schlüsselwörter \\ Thrombozytenapherese - Apherese - Amicus - COM.TEC . \\ Zellseparator
}

\section{Zusammenfassung}

Hintergrund: Eine Reihe von Apheresevorrichtungen für die Thrombozytenapherese ist mittlerweile auf dem Markt verfügbar. In der vorliegenden Arbeit werden zwei Apheresevorrichtungen (Fenwal Amicus und Fresenius COM.TEC) hinsichtlich der Parameter Separationszeit, Thrombozytengehalt und -effizienz sowie Gehalt an weißen Blutzellen (WBC) verglichen. Material and Methoden: Spender, bei denen eine Thrombozytenapherese zum Einsatz kam, wurden randomisiert auf zwei Gruppen verteilt (entweder Amicus- oder COM.TEC-Zellseparator. Ergebnisse: In einem Vorapherese-Setting zeigten 32 Thrombozytenapheresevorgänge, die mit jedem Instrument durchgeführt wurden, keine signifikanten Unterschiede hinsichtlich Geschlecht, Alter, Gewicht, Größe und Gesamtblutvolumen des Spenders zwischen den beiden Gruppen. Allerdings war der Präapherese-Thrombozytengehalt mit dem COM.TEC höher als mit dem Amicus $\left(198 \times 10^{3} / \mu \mathrm{l}\right.$ vs. $223 \times 10^{3} / \mu \mathrm{l} ; \mathrm{p}=$ $0,035)$. Das prozessierte Blutvolumen, das zur Erreichung des Ziel-Thrombozytengehalts von $\geq 3,3 \times 10^{11}$ benötigt wurde, war beim COM.TEC höher als beim Amicus (3481 vs. $2850 \mathrm{ml}$; $\mathrm{p}<$ $0,001)$. Die mediane Separationszeit war beim COM.TEC signifikant höher als beim Amicus (61 vs. 44 min; $p<0,001$ ). 99 bzw. $88 \%$ der Thrombozytenprodukte, die mit dem Amicus bzw. mit dem COM.TEC gesammelt wurden, hatten einen Thrombozytengehalt von $\geq 3,3 \times 10^{11}(p=0,325)$. Sämtliche mit beiden Geräten gewonnenen Produkte wiesen die vorgeschriebene WBCAnzahl von $<5 \times 10^{6}$ auf. In Bezug auf die Sammlungseffizienz gab es keine Unterschiede zwischen den beiden Geräten ( $55 \pm$ 15 vs. $57 \pm 15 \% ; p=0,477$ ). Allerdings war die Sammelrate beim Amicus signifikant höher als beim COM.TEC $(0,077 \pm 0,012 \times$ $10^{11}$ vs. $\left.0,057 \pm 0,008 \times 10^{11} \mathrm{PLT} / \mathrm{min} ; \mathrm{p}<0,001\right)$. Schlussfolgerung: Beide Geräte eignen sich zur effizienten Sammlung von Thrombozyten. Zusätzlich wird mit beiden Geräten eine deutliche Leukoreduktion erzielt. Allerdings lässt sich mit dem Amicus der Ziel-Thrombozytengehalt schneller erreichen als mit dem COM.TEC.

\begin{tabular}{ll}
\hline KARGER & @ 2008 S. Karger GmbH, Freiburg \\
Fax +497614520714 & Accessible online at: \\
Information@Karger.de & www.karger.com/tmh \\
www.karger.com &
\end{tabular}




\section{Introduction}

There are many advantages to donor plateletpheresis. Among these are the following: economic use of blood due to selective collection of a relatively large amount of components, possibility of more frequent donations, elimination of unnecessary component separation in the laboratory, reduced donor exposures and therefore reduced risk of disease transmission and risk of human leukocyte antigen (HLA) alloimmunization, use as an effective treatment for already alloimmunized patients, and labeling as 'leukoreduced' without further manipulation [1-5]. Although improvements in apheresis technology are ongoing, some problems do remain, e.g. the duration of the procedure and donor discomfort owing to the citrate used for anticoagulation. Minimization of these variables is the driving motivation behind new apheresis instrument development. Presently, there are a variety of plateletpheresis instruments available on the market, and several studies focusing on the comparison of different plateletpheresis cell separators have been conducted [6-13]. There is, however, no published data comparing the Fenwal Amicus and the Fresenius COM.TEC cell separators.

In the present study, we compared plateletpheresis on the Fenwal Amicus cell separator (Baxter Healthcare, Deerfield, IL, USA) and the COM.TEC cell separator (Fresenius HemoCare GmbH, Bad Homburg, Germany) with respect to separation parameters and platelet (PLT) yield characteristics such as processing times, PLT yields, separation efficiencies, and white blood cell (WBC) content.

\section{Materials and Methods}

The study included all healthy volunteer donors between January 2006 and December 2006 who met the Council of Europe Guidelines and Recommendations for apheresis and the standard guidelines established by the American Association of Blood Banks [14, 15]. Criteria for eligibility for a single unit $\left(\geq 3.3 \times 10^{11}\right)$ were as follows: 1$)$ age $18-60$ years, 2$)$ preapheresis peripheral blood (PB) PLT count $\geq 150 \times 10^{9} / 1,3$ ) hemoglobin $(\mathrm{Hb})$ level $\geq 13.5 \mathrm{~g} / \mathrm{dl}, 4$ ) donor body weight $\geq 50 \mathrm{~kg}, 5$ ) negative tests for HIV, hepatitis B surface antigen, hepatitis C, and syphilis, 6) absence of any illness, 7) in good health and feeling well, 8) adequate venous accesses, 9) at least 3 months since last whole blood donation, 10) at least 3 days since last plateletpheresis, and 11) no consumption of non-steroidal antiinflammatory drugs and acetyl salicylic acid in the last 7 days [16].

The study was approved by the Institutional Review Board. Written consent was obtained after procedural risks were explained in detail before the procedure. Plateletpheresis donors were sequentially assigned to either the Baxter Amicus cell separator or the Fresenius COM.TEC device. Antecubital veins were used for the venipuncture in all the donors. Senior apheresis technicians performed all procedures. Vital signs were monitored at the beginning and end of each procedure; donors were also monitored for adverse events during the apheresis procedures. Pre-procedure donors' height, weight, sex, and total blood volume (TBV) were also recorded. None of the donors received routine prophylactic oral or intravenous calcium during the apheresis procedure.

\section{Instruments}

A single Fenwal Amicus instrument with software version 2.52 (Baxter Healthcare, Deerfield, IL, USA) was used. A double venous access with a plateletpheresis kit was used per the manufacturer's recommendation. The parameters of the Amicus device were as follows: whole blood flow $55-80 \mathrm{ml} / \mathrm{min}$, interface set point 0.60 , and anticoagulant/whole blood ratio 1:8-11. The second cell separator used for PLT collection was the blood cell separator COM.TEC, software version 4.0 (Fresenius HemoCare $\mathrm{GmbH}$, Bad Homburg, Germany). Per the manufacturer's recommendations, we used a double venous access with a C5L kit in a dual-needle procedure (program PLT5d DN). The machine parameters were as follows: whole blood flow 50-75 $\mathrm{ml} / \mathrm{min}$, interface set point 33 , and anticoagulant/whole blood ratio 1:8-12. The following data were entered into the cell separator program for both instruments: donors' height, weight, sex, hematocrit (Htc) and pre-apheresis PB platelet count. The processed blood volume to reach the target PLT yield $\left(\geq 3.3 \times 10^{11}\right)$ was determined by both instruments. No additional post-procedure processing or filtration to obtain leukoreduced products was performed on either instrument.

\section{Peripheral Blood Variables}

Peripheral blood samples ( $2 \mathrm{ml}$, ethylene diamine tetraacetate (EDTA)) were drawn from each donor prior to and $2 \mathrm{~h}$ after completion of apheresis. Pre- and post-apheresis complete blood count (CBC) analysis was performed. Donor PLT loss was analyzed using the following formula: PLT loss $=($ pre-PLT count - post-PLT count $) \times 100 /$ pre-PLT count .

\section{Operational Variables}

We recorded all procedure times, the processed blood volume to reach the PLT target yield, the flow rate, and the acid citrate dextrose-A (ACDA) volume used.

\section{Platelet Yield Variables}

After the PLT container had rested for $1 \mathrm{~h}$ without agitation, we obtained plateletpheresis yield samples with EDTA $(2 \mathrm{ml})$ from the PLT bag for laboratory analysis. The yield was analyzed for volume, the numbers of WBC, red blood cells (RBC), and PLT, and swirling. Collection efficiency (CE) was calculated by the following formulas:

$\mathrm{CE}=$ total PLT yield $\left(10^{11}\right) \times 100 /($ pre-apheresis PLT count + postapheresis PLT count $/ 2) \times$ blood volume processed

Blood volume processed $=\mathrm{TBV}$ processed $-\mathrm{ACD}-\mathrm{A}(\mathrm{ml})$

Collection rate (CR) was calculated by the formula:

$\mathrm{CR}=\mathrm{PLT}$ yield $/$ separation time

The ratio of PLT yield/blood volume processed was also calculated. Complete blood counts were determined using an automated blood cell counter (Sysmex XT 2000i, Roche diagnostics, Sysmex Corporation, Kobe, Japan), swirling was observed against light, and residual leukocyte concentrations in the PLT concentrate were determined by flow cytometry on a FACS Calibur (Becton Dickinson, Franklin Lakes, NJ, USA) in plateletpheresis yields.

\section{Statistics}

Data were expressed as the median (range) and mean \pm standard deviation (SD). The Amicus and the COM.TEC instruments were compared 
Table 1. Donors' characteristics

\begin{tabular}{llll}
\hline & $\begin{array}{l}\text { Amicus } \\
(\mathrm{n}=32)\end{array}$ & $\begin{array}{l}\text { COM.TEC } \\
(\mathrm{n}=32)\end{array}$ & $\begin{array}{l}\mathrm{p} \\
\text { value }\end{array}$ \\
\hline Male/female & $29 / 3$ & $30 / 2$ & 0.644 \\
Age, years; median (range) & $28(18-43)$ & $29(21-49)$ & 0.146 \\
Weight, kg; mean \pm SD & $73.9 \pm 10.4$ & $74.1 \pm 7.1$ & 0.946 \\
Height, cm; median (range) & $170(155-185)$ & $170(163-180)$ & 0.839 \\
TBV, ml; mean \pm SD & $5,142 \pm 778$ & $5,197 \pm 464$ & 0.696 \\
TBV = Total blood volume. & & & \\
\hline
\end{tabular}

using an unpaired t-test or the Mann Whitney U test with regard to preand post-apheresis peripheral blood variables, plateletpheresis operational variables and product variables. An unpaired t-test was used for peripheral blood variables (e.g. pre-apheresis $\mathrm{Hb}$, pre-apheresis Htc level, post-apheresis $\mathrm{Hb}$ level and post-apheresis Htc level, TBV, body weight of donor) and plateletpheresis product variables (e.g. collection rate), which were within normal distribution. The Mann Whitney U test was used for peripheral blood variables (e.g. pre-apheresis WBC count, pre-apheresis PLT count, post-apheresis PLT count, post-apheresis WBC count and $\mathrm{Hb}$ loss $\%$ and PLT loss \%), plateletpheresis operational variables (e.g. blood volume processed, flow rate, product volume and separation time) and plateletpheresis product variables (e.g. $\mathrm{pH}, \mathrm{WBC}$ count/bag and PLT count/bag), which were not within normal distribution. Data were analyzed on the SPSS software platform (SPSS 13.0, Chicago, IL, USA). The level of significance was set at $\mathrm{p}<0.05$.

\section{Results}

The general characteristics of in total 64 donors $(n=32$ in the Amicus group and $\mathrm{n}=32$ in the COM.TEC group) are given in table 1 . The median age of the donors was 28 (range, 18-43 years) and 29 years (range, 21-49 years) for the Amicus group and the COM.TEC group, respectively. While there were 29 males and 3 females in the Amicus group, there were 30 males and 2 females in the COM.TEC group. There was also no statistically significant difference between the two groups in terms of weight, height, and TBV of the donors.

\section{Pre- and Post-Apheresis Peripheral Blood Variables}

Pre- and post-apheresis PB data are shown in table 2. There were no significant differences in pre-apheresis $\mathrm{Hb}$ levels, Htc levels, and WBC counts. However, the pre-apheresis PLT count was significantly higher in patients on the COM.TEC instrument compared to the Amicus $\left(198 \times 10^{3} / \mu \mathrm{l}\right.$ vs. $223 \times$ $\left.10^{3} / \mu \mathrm{l} ; \mathrm{p}=0.035\right)$; no statistical differences in post-apheresis $\mathrm{PB} \mathrm{Hb}$ and Htc levels were noted between the instruments. The post-apheresis PLT count was significantly lower in the Amicus compared to the COM.TEC group $\left(144 \times 10^{3} / \mu \mathrm{l}\right.$ vs. $\left.164 \times 10^{3} / \mu \mathrm{l} ; \mathrm{p}=0.019\right)$; there were, however, no statistically significant differences between the percentages of PLT and Hb loss (table 2).

\section{Plateletpheresis Operational Variables}

The median blood volume processed to reach a PLT yield $\geq 3.3 \times 10^{11}$ was significantly higher with the COM.TEC compared to the Amicus $(3,481$ vs. $2,850 \mathrm{ml} ; \mathrm{p}<0.001)$. Additionally, the median flow rate of the Amicus was significantly higher than the median flow rate of the COM.TEC (65 vs. $58 \mathrm{ml} / \mathrm{min}$; $\mathrm{p}<0.001)$. Furthermore, there was a significantly higher median volume of ACD used in collections on the COM.TEC (373 vs. $300 \mathrm{ml}$; $\mathrm{p}<0.001$ ). However, the mean citrate load per minute was higher in the Amicus compared to the COM.TEC $(6.6 \pm 0.8$ vs. $6.1 \pm 0.5 \mathrm{ml} / \mathrm{min})(\mathrm{p}=0.042)$. The median time needed for the procedures was also significantly longer with the COM.TEC (61 vs. $44 \mathrm{~min} ; \mathrm{p}<0.001$ ). The plateletpheresis procedure data are shown table 3 .

\section{Plateletpheresis Product Variables}

The plateletpheresis product variables are summarized in table 4. There were no significant differences in terms of swirling percent, PLT yield/bag, and WBC count/bag (table 4). However, PLT yield/blood volume processed was significantly higher with the Amicus (0.42 vs. 0.33; $\mathrm{p}<0.001$ ). The percentage of PLT yield $\geq 3.3 \times 10^{11 / b a g}$ was $91 \%$ (29/32) and $88 \%$ (28/32) on the Amicus and the COM.TEC instrument, respectively $(\mathrm{p}=0.325)$. A CE of $55 \pm 15 \%$ was obtained on the Amicus and $57 \pm 15 \%$ on the COM.TEC $(\mathrm{p}=0.477)$. However, the $\mathrm{CR}$ was statistically higher with the Amicus $(0.077 \pm 0.012$ $\times 10^{11}$ vs. $\left.0.057 \pm 0.008 \times 10^{11} \mathrm{PLT} / \mathrm{min} ; \mathrm{p}<0.001\right)$. All products obtained with both instruments had WBC counts lower than $5 \times 10^{6}$, as required. Additionally, the number of products with $<1 \times 10^{6}$ WBC was $30(94 \%)$ with the Amicus and $28(87 \%)$ with the COM.TEC $(\mathrm{p}=0.325)$.

\section{Adverse Effects of Plateletpheresis}

There were no high-rate adverse events that would cause early termination of the procedure. However, citrate-related mild toxicity occurred more commonly on the COM.TEC (6 donors) than on the Amicus (4 donors), due probably to the larger amounts of ACD-A used (300 vs. $373 \mathrm{ml}$; $\mathrm{p}<0.001)$. All reactions responded rapidly to decreased flow rates and/or oral calcium supplementation.

\section{Discussion}

Although a variety of apheresis devices are currently available on the market for plateletpheresis procedures, there are scant data concerning plateletpheresis with the COM.TEC machine $[13,17,18]$. Additionally, there is no published data comparing the COM.TEC and the Amicus instruments used for platelet- 
Table 2. Pre-and post-apheresis donor $\mathrm{CBC}$

\begin{tabular}{llll}
\hline & Amicus & COM.TEC & p value \\
\hline Pre-apheresis WBC $\left(\times 10^{3} / \mu \mathrm{l}\right)$; median (range) & $6.95(4.4-11.2)$ & $7.55(5.1-10.4)$ & 0.07 \\
Post-apheresis WBC $\left(\times 10^{3} / \mu \mathrm{l}\right)$; median (range) & $6.6(3.9-9.7)$ & $6.5(4.0-10.0)$ & 0.746 \\
WBC loss, \%; median $(\mathrm{range})$ & $11.5(0-36.2)$ & $16(0-25)$ & 0.05 \\
Pre-apheresis Hb level, g/dl; mean \pm SD & $15.6 \pm 1.4$ & $15.4 \pm 1.3$ & 0.540 \\
Post-apheresis Hb level, g/dl; mean \pm SD & $14.6 \pm 1.5$ & $14.5 \pm 1.5$ & 0.882 \\
Hb loss \%; median $($ range) & $6.5(0-9.3)$ & $6.3(3.3-13.6)$ & 0.605 \\
Pre-apheresis Htc level, \% & $44.5 \pm 2.7$ & $43.5 \pm 3.2$ & 0.259 \\
Post-apheresis Htc level, \% & $41.4 \pm 3.1$ & $41.7 \pm 4.2$ & 0.979 \\
Htc loss, \%; median $($ range) & $5.5(2.2-18.4)$ & $5.9(0-9.9)$ & 0.171 \\
Pre-apheresis PLT count $\left(\times 10^{3} / \mu 1\right)$; median (range) & $198(159-313)$ & $223(180-248)$ & $0.035^{*}$ \\
Post-apheresis PLT count $\left(\times 10^{3} / \mu \mathrm{l}\right)$; median (range) & $144(105-206)$ & $164(109-237)$ & $0.019^{*}$ \\
PLT loss, \%; median $($ range $)$ & $32(19-40)$ & $29(3-39)$ & 0.07 \\
\hline
\end{tabular}

$\mathrm{WBC}=$ White blood cell $; \mathrm{Hb}=$ hemoglobin $; \mathrm{Htc}=$ hematocrit PLT $=$ platelet. ${ }^{*} \mathrm{p}=$ Statistically significant.

Table 3. Plateletpheresis kinetics and procedural data

Table 4. Plateletpheresis product data

\begin{tabular}{llll}
\hline & Amicus & COM.TEC & p value \\
\hline Blood volume processed, ml; median (range) & $2,850(2,500-3,500)$ & $3,481(2,742-4,139)$ & $<0.001$ \\
Flow rate, ml/min; median (range) & $65(55-75)$ & $58(50-65)$ & $<0.001$ \\
ACD-A volume, ml; median (range) & $300(210-341)$ & $373(294-407)$ & $<0.001$ \\
Separation time, min; median (range) & $44(37-58)$ & $61(48-72)$ & $<0.001$ \\
Product volume, ml; median (range) & $285(260-340)$ & $300(300-304)$ & $<0.001$ \\
\hline
\end{tabular}

\begin{tabular}{llll}
\hline & Amicus & COM.TEC & p value \\
\hline Swirling percent & 100 & 100 & \\
PLT yield/bag $\left(\times 10^{11}\right)$; median $($ range $)$ & $3.39(2.84-4.03)$ & $3.33(2.87-3.94)$ & 0.185 \\
Number of PLT yield $\geq 3.3 \times 10^{11} / \mathrm{bag}$ & $29 / 32(91 \%)$ & $28 / 32(88 \%)$ & 0.325 \\
PLT yield/blood volume processed & 0.42 & 0.33 & $<0.001^{*}$ \\
WBC count/bag $\left(\times 10^{6}\right)$; median $($ range $)$ & $0.30(0.30-1.20)$ & $0.57(0.26-1.43)$ & 0.805 \\
Number of yield with WBC $<1 \times 10^{6}$ & $30(94 \%)$ & $28(87 \%)$ & 0.399 \\
RBC count/bag $\left(\times 10^{6}\right) ;$ mean \pm SD & $4.3 \pm 10.2$ & $13.18 \pm 15.18$ & $0.008^{*}$ \\
Collection efficiency, \%; mean \pm SD & $55 \pm 15$ & $57 \pm 15$ & 0.477 \\
Collection rate $\left(\right.$ PLT $10^{11} /$ min $)$; mean \pm SD & $0.077 \pm 0.012$ & $0.057 \pm 0.008$ & $<0.001^{*}$ \\
\hline
\end{tabular}

$\mathrm{PLT}=$ platelet, $\mathrm{WBC}=$ white blood cell.

* $\mathrm{p}=$ Statistically significant. pheresis. This study documents the features of the COM.TEC and compares it to the widely used Amicus instrument with respect to parameters such as separation time, PLT yield, CE, and WBC content. In today's world, productivity, i.e. 'doing more in less time', is as key a feature as yield when evaluating equipment. Coffe et al. [17] recorded the French experience on plateletpheresis with the COM.TEC cell separator; the blood volume processed was 4,606-5,229 1, and the mean separation time was between $87-109 \mathrm{~min}$ to reach a target PLT yield of $4.74 \times 10^{11}$ to $5.95 \times 10^{11}$ with the COM.TEC machine. Moog et al. [18] reported an average processed blood volume of 2,826 $\pm 409 \mathrm{ml}$ in a donation time of $55 \pm 11 \mathrm{~min}$; the mean
PLT yield of these products was $3.11 \pm 0.40 \times 10^{11}$. Strasser et al. [13] reported a processed blood volume of $2.49 \pm 0.501$ and a mean separation time of $54 \pm 13$ min for a mean PLT yield of $2.90 \pm 0.54 \times 10^{11}$ PLT using the COM.TEC. Burgstaler et al. [9] recorded median separation times of $77 \mathrm{~min}$ for a median PLT yield of $5.03 \times 10^{11}$ with the Amicus. Additionally, Benjamin et al. [10] reported average separation times of $71.5 \mathrm{~min}$ for median yields of $4.9 \times 10^{11}$ PLT using the Amicus. In this study, the median blood volume processed to reach a target PLT yield of $3.3 \times 10^{11}$ was significantly higher with the COM.TEC $(3,481$ vs. $2,850 \mathrm{ml} ; \mathrm{p}<0.001)$. For this reason, there was a significantly longer mean separation time with the 
COM.TEC (61 vs. 44 min; $\mathrm{p}<0.001$ ). On the other hand, they do report that sex, age, weight, TBV and pre-procedure PLT count affect PLT yield $[13,18]$. In the present study, no significant differences were noted with regard to sex, age, weight, height and TBV between the two instruments; however, the median pre-procedure PLT counts were significantly different $\left(198 \times 10^{3} / 1\right.$ vs. $\left.223 \times 10^{3} / 1 ; p=0.035\right)$. This difference in the pre-apheresis PLT counts between the two groups may be due to insufficient numbers of donors per study arm as well as to performing in different subsequent time periods. Additionally, there was no statistically significant difference with respect to the median PLT yield of products per component between the separators $\left(3.39 \times 10^{11}\right.$ vs. $\left.3.33 \times 10^{11} ; \mathrm{p}=0.185\right)$.

One important advantage of plateletpheresis is that no further manipulation is required for the product to be labeled as 'leukoreduced'. Leukocytes must be $<5 \times 10^{6}$ per concentrate according to USA standards and $<1 \times 10^{6}$ per concentrate according to European standards [14, 15]. Coffe et al. [17] reported that the residual leukocyte levels were $<1 \times 10^{6}$ per concentrate (mean $0.233 \pm 0.150 \times 10^{6}$ ) in more than $97 \%$ of the components produced (confidence interval (CI) of $>95 \%$ ). Moog et al. [18] recorded mean WBC contaminations of 0.11 $\pm 0.20 \times 10^{6}$ with the COM.TEC. Strasser et al. [13] reported that nearly all of the PLT products collected with the COM.TEC, the AS.TEC204, and the COBE spectra met the AABB standards as well as the more stringent European guidelines. Using the Amicus, Laurencet et al. [20] reported $<5 \times 10^{6} \mathrm{WBC}$ in $98 \%$ of the products and $<1 \times 10^{6} \mathrm{WBC}$ in $84 \%$. Additionally, some studies have confirmed the consistency of leukoreduction [9-11, 21]. In the present study, all products obtained with both instruments had a WBC content $<5 \times 10^{6}\left(0.30 \times 10^{6}\right.$ to $1.2 \times 10^{6}$ vs. $0.26 \times 10^{6}$ to $1.43 \times 10^{6} ; \mathrm{p}=$ $0.805)$. Additionally, the number of products with $<1 \times 10^{6}$ WBC was 30 (94\%) with the Amicus and 28 (87\%) with the COM.TEC instrument $(\mathrm{p}=0.325)$.

Efficient PLT collection is an important issue when comparing instruments; the new generation of instruments appears to be more efficient [9]. In the present study, we noted a CE of $55 \pm$ $15 \%$ with the Amicus and of $57 \pm 15 \%$ with the COM.TEC $(p=0.477)$. Compared to results reported in the literature, our COM.TEC CE results $(57 \pm 15 \%)$ were similar to those reported: $52-55 \%$ [13, 17, 18]. However, our Amicus results $(55 \pm 15 \%)$ were lower than the reported averages of $66-73 \%$ [8-11, 19-22]. On the other hand, when comparing the instruments with regard to PLT yield/blood volume processed, the Amicus showed a significantly higher ratio compared to the COM.TEC ( 0.42 vs. $0.33 ; \mathrm{p}<0.001)$. Moreover, while the CR was statistically higher with the Amicus $(0.077 \pm 0.012$ vs. 0.057 $\pm 0.008 ; \mathrm{p}<0.001$ ), the CR of both machines was comparable to that reported in the literature $[8,9,20,23]$.

Efficient platelet collection with fewer procedure-related side effects is an important consideration for donors. The most common procedural adverse effects are citrate related [16-18, 24]; the incidence of citrate toxicity varies from 0.11 to $16 \%$ in different studies [8, 25-28]. Citrate-related reactions have been observed in $0.5 \%$ of cases on the COM.TEC machine [17]. Additionally, Benjamin et al. [10] reported that mild citrate-related toxicity occurred more commonly on the Amicus than on the Spectra LRS separator, as a result of the larger amount of ACD used (483 vs. $389 \mathrm{ml} ; \mathrm{p}<0.0001$ ). However, these adverse reactions were successfully treated by reducing the ACD infusion rate, the amount of ACD used and/or oral calcium supplementation $[13,17,18]$. In the present study, since there were significant differences between the flow rates of the devices, separation time and ACD consumption were also found to be statistically significant ( $\mathrm{p}<0.001)$. Additionally, there were statistically significant differences between the two groups in terms of the citrate load per minute $(\mathrm{p}=0.042)$. The higher ACD consumption but lower citrate load per minute of the COM.TEC procedure may be explained with the low number of donors per arm. Citrate-related mild toxicity occurred more commonly on the COM.TEC (6 donors) than on the Amicus (4 donors). However, this was not clinically significant.

In conclusion, both instruments perform plateletpheresis efficiently. Additionally, consistent leukoreduction was obtained with both machines. The Amicus, however, has the advantage of a lower separation time.

\section{References}

1 Price TH: Provision of single-donor platelet transfusions: Patient and producer perspectives; in McLeod BC, Price TH, Weinstein R (eds): Apheresis: Principals and Practice. Bethesda, AABB Press, 2003, pp 185-197.

2 Vassallo R, Murphy S: Platelet functions, kinetics and metabolism: Impact on quality assessment, storage and clinical use; in McLeod BC, Price TH, Weinstein R (eds): Apheresis: Principals and Practice. Bethesda, AABB Press, 2003, pp 161-183.

$\checkmark 3$ Ness P, Braine H, King K, Barrasso C, Kickler T, Fuller A, Blades N: Single-donor platelets reduce the risk of septic platelet transfusion reactions. Transfusion 2001;41:857-861.

4 Slichter SJ: Platelet refractoriness and alloimmunization. Leukemia 1998;12:51-53.
5 Schreiber GB, Busch MP, Kleinman SH, Korelitz JJ: The risk of transfusion-transmitted viral infections. The Retrovirus Epidemiology Donor Study. N Engl J Med 1996;334:1685-1690.

6 Burgstaler EA, Pineda AA, Brecher MA: Plateletapheresis: comparison of platelet yields, processing time, and white blood cell content with two apheresis systems. Transfusion 1993;33:393-398.

7 Beyan C, Cetin T, Kaptan K, Nevruz O: Effect of plateletpheresis on complete blood count values using three different cell separator systems in healthy donors. Transfus Apher Sci 2003;29:45-47.

$\checkmark 8$ Burgstaler EA, Pineda AA, Wollan P: Plateletapheresis: Comparison of processing times, platelet yields, and white blood cell content with several commonly used systems. J Clin Apher 1997;12: $170-178$.
9 Burgstaler EA, Pineda AA, Bryant SC: Prospective comparison of plateletapheresis using four apheresis systems on the same donors. J Clin Apher 1999; 14:163-170.

10 Benjamin RJ, Rojas P, Christmas S, Neal J, Broughton S, Burgio C, Barrett B, Churchill WH: Plateletapheresis efficiency: a comparison of the Spectra LRS and Amicus seperators. Transfusion 1999;39:895-899.

11 Moog R, Muller N, Goergens D: Platelet collection with the Amicus and AS.TEC 204 blood cell separators. Transfusion 1998;38:285-289.

12 Ranganathan S: Comparison of plateletapheresis on the Fresenius AS.TEC 204 and Haemonetics MCS 3p. J Clin Apher 2007;22:1-4. 
13 Strasser EF, Schuster M, Egler K, Bauer J, Weisbach V, Ringwald J, Zimmermann J, Zingsem J, Eckstein R: Frequently used plateletpheresis techniques result in variable target yields and platelet recruitment of donors. Transfusion 2005;45: 788-797.

14 Council of Europe Guide to the preparation, use and quality assurance of blood components, ed 10 Strasbourg, Council of Europe Press, 2004.

15 Fridey JL (ed): Standards for blood banks and transfusion services, ed 22. Bethesda, American Association of Blood Banks, 2003.

16 Randels MJ: Selection and care of apheresis donors; in McLeod BC, Price TH, Weinstein R (eds): Apheresis: Principals and Practice. Bethesda, AABB Press, 2003, pp 131-142.

17 Coffe C, Benguella M, Domy M, Cottier D, Guignier F, N'gondara JP, Carrere A, Masse M, Naegelen C, Biggio B, Tiberghien P, Herve P, Bouzgarrou R, Maurel JP, Vezon G, Vidal M, Quainon F, Benamara A, Lamy B, Beaumont JL, Bierling $\mathrm{P}$, Gondrexon G, Schooneman F, Janot C, Villard F Huart JJ: Plateletpheresis concentrates produced with the COMTEC cell separator: the French experience. Transfus Apher Sci 2001;25:67-72.
18 Moog R, Zeiler T, Heuft HG, Stephan B, Fischer EG, Kretschmer V, Rödel-Spieker R, Strasser E, Zingsem J: Collection of WBC-reduced singledonor PLT concentrates with a new blood cell separator: results of a multicenter study. Transfusion 2003;43:1107-1114.

19 Kalish RI, Chambers LA, Linden JV: The effect of plateletapheresis on the Fenwal CS3000 on donor platelet counts. J Clin Apher 1987;3:230-234.

20 Laurencet FM, Doucet A, Lydiate V, Jacquier MC, Mermillod B, Andersen S, Chapuis B: Quality evaluation of plateletapheresis using the new Amicus (Baxter) cell separator: evolution of CD62 expression. J Clin Apher 1998;13:47-55.

21 Yockey C, Murphy S, Eggers L, Garratty G, Dingle A, Helms C, Moroff G: Evaluation of the Amicus separator in the collection of apheresis platelets. Transfusion 1998;38:848-854.

22 Schooneman F: Deleukocytation of plateletpheresis concentrates obtained with the use of Amicus cell separators. Transfus Apher Sci 2001;25:61-62.
23 Moog R, Muller N: Evaluation of the single needle procedure in plateletapheresis with Fresenius AS104 blood cell separator. J Clin Apher 1995;10: 90-95.

24 McLeod BC, Price TH, Owen H, Ciavarella D, Sniecinski I, Randels MJ, Smith JW: Frequency of immediate adverse effects associated with apheresis donation. Transfusion 1998;38:938-943.

25 Bueno JL, Barea L, Garcia F, Castro E: A comparison of PLT collections from two apheresis devices. Transfusion 2004;44:119-124.

26 Despotis GJ, Goodnough LT, Baorto D, Spitznagel E: Adverse events in platelet apheresis donors: a multivariate analysis in a hospital based programme. Vox Sang 1999;77:24-32.

27 Makar YF, Butler MO, Cockersole GM, Gabra G, Serevitch JM: National audit of citrate toxicity in plateletpheresis donors. Transfus Med 2002;12: 187-191.

28 Strauss RG: Safety of donating multiple products in a single apheresis collection: are we expecting too much? J Clin Apher 2003;18:135-140. 